\title{
AMERICAN TAX CONSIDERATIONS IN THE DRAFTING OF CANADIAN JOINT OPERATING AGREEMENTS
}

\author{
JOHN F CURRAN*
}

\begin{abstract}
Many operators in Canada's oil and gas industry are subject to taxation under the United States Internal Revenue Code. In their Canadian activities, operations and agreements, these operators seek to preserve any tax benefits that they may have under the income tax laws of the United States. This article outlines the tax advantages which the United States operator wishes to preserve, such as avoidance of the status of an association taxable as a corporation, exclusion from the partnership taxation provisions of the Code, and the option to expense intangible drilling and development costs; discusses the effect of these provisions on Canadian operators not subject to United States tax laws, and suggests draft clauses that may be included in Canadian joint operating agreements to preserve United States tax benefits for the American operator.
\end{abstract}

\section{A. INTRODUCTION}

This paper is concerned with American income tax law as it bears upon the form, and to some extent the substance, of typical joint operating agreements ${ }^{1}$ in use in the petroleum industry in Canada. As a result of the substantial number of American operators who participate in the Canadian petroleum industry, joint operating agreements involving these operators contain provisions which are designed to preserve certain tax benefits under the United States Internal Revenue Code" and attendant regulations.

Most Canadian lawyers who draft oil and gas joint operating agreements are familiar with the provisions that are normally included for the benefit of the American operators. Experience indicates, however, that some uncertainty still exists among Canadian lawyers about why certain provisions are required, how they are to be drafted, and to what extent they may involve a Canadian operator who is not otherwise concerned with American income tax law.

This paper deals with all three aspects of the uncertainty. It will be seen that the tax conscious draftsman's chief concern is to avoid drafting a joint operating agreement with features that the United States Internal Revenue Service has said will result in the classification of the agreement for United States income tax purposes as a partnership or association taxable as a corporation. Before discussing the drafting of the joint operating agreement something by way of introduction should be said about how joint operating agreement partnerships and associations are treated under the United States income tax law and about certain administrative rulings of the United States Internal Revenue Service which lay down some guidelines for drafting of joint operating agreements.

- Barrister and Solicitor, Saucier, Jones, Peacock, Black, Gain, Stratton and Laycraft, Calgary, Alberta.

1 For a discussion of the terms of a typical Canadian joint exploration and development operating agreement see Burden. The Operating Agreement-for the Development of operating agreement see Burden, The Operating Agreement-for the Development of
Petroleum and Natural Gas Resources, (1965) 30 Sask. Bar Rev. 325. Joint operating Petroleum and Natural Gas Resources, (1965) 30 Sask. Bar Rev. 325. Joint operating
agreements, whether related to exploration and development, unitization or processing and manufacturing operations, all have many provisions in common which are designed to avoid unwanted involvement with United States income tax law.

2 Internal Revenue Code, 1954, hereinafter referred to as the "Code". 


\section{B. ORGANIZATION CLASSIFIED AS A PARTNERSHIP}

The question of partnership classification of a joint operating agreement is significant because of the existence of subchapter $K$ of the Code which contains the provisions for taxation of partnerships. Under section 7701 of the Internal Revenue Code "partnership" includes:

a syndicate, group, pool, joint venture, or other unincorporated organization through or by means of which any business, financial operation, or venture is carried on, and which is not within the meaning of this title, a corporation or a trust or estate.

It is interesting to compare this definition with the definition of "partnership" in section 2 (c) of The Partnership Act of Alberta: ${ }^{3}$

"partnership" means the relationship that subsists between persons carrying on a business in common with a view to profit;

The Alberta definition is substantially the same as that contained in the Partnership Acts of the western provinces and emphasizes the "business" and "profit" aspects of the relationship. The Code's definition is much broader in scope and may include every conceivable organization typically used to conduct joint operations in the Canadian petroleum industry. ${ }^{4}$

There are many distinctions between the typical joint operating agreement and the ordinary concept of partnership, despite the broad definition of that word in section 7701 and in section 761 (a) " of subchapter $\mathbf{K}$ of the Code, and there are advantages and disadvantages in conducting joint operations under an operating agreement partnership. It would appear from the number of American operators in Canada electing not to be treated for United States income tax purposes as members of joint operating partnerships, that the disadvantages of conducting joint operations as partnerships usually outweigh any advantages that might exist. A discussion of all the advantages and disadvantages accompanying partnership tax classification is not within the scope of this paper but the mention of a few may be useful.

One advantage of a partnership tax classification is that the income and expenses of the partners are to be determined by the joint operating agreement. The partners have complete freedom to provide for the treatment of any item of income or expense as they choose. As an example the partners may agree that certain expenses, such as intangible drilling and development costs" are to be shared on one basis, while depletion and depreciation are to be shared on another. It should be emphasized, however, that advantageous arrangements which the partners make, may be challenged by the Internal Revenue Service, if the arrangements do not have a substantive business purpose and the Internal Revenue Service can establish that the purpose of the arrangements is tax avoidance. If a substantive business purpose exists for the

3 R.S.A. 1955, c. 230.

I It goes without saying that, although under Canadian law joint operations are not necessarily partnerships, they may be partnerships for purposes of the Code and the American operator could be treated under the Code as a member of a partnership and its income from the operations would be taxed accordingly.

$\therefore$ "For purposes of this Subtitle, the term 'partnership' includes a syndicate, group, pool, joint venture, or other unincorporated organization through or by means of which any business, financial operation, or venture is carried on, and which is not, within any business, financial operation, or venture is carried on, and which is not. within $\mathrm{K}$ of the Code contains the provisions for taxation of partnerships.

- For an explanation of the meaning of "Intangible drilling and development costs" and treatment of the subject generally, see pp. 205-9, below. 
arrangements between the partners, even though there is a direct income tax reducing effect, the arrangements will be left unchallenged.

There are important disadvantages of a partnership tax classification. Firstly, because the typical Canadian joint operating agreement contains provisions ${ }^{i}$ which clearly indicate that the co-owners do not intend to be a partnership, partnership classification might result in consequences not desired or anticipated by the American operator. Secondly, a number of accounting and reporting problems exist which the operator wishes to avoid. For instance, it would be difficult, if not impossible, for the partnership to compute ${ }^{s}$ and file a partnership return because the income from the sale of production is usually paid directly to each co-owner by the purchaser. Furthermore, the operator usually has no knowledge of the expenses attributable to a particular co-owner's income except the direct expenses incurred by the operator. To eliminate these difficulties a number of unusual accounting practices and reporting procedures would have to be adopted. Thirdly, all elections" affecting the computation of taxable income derived from a partnership must be made by the partnership. Among such elections is the election to expense rather than capitalize intangible drilling and development costs. ${ }^{10}$ If the partnership entity fails to make this election, neither the partnership nor the partners can expense these costs. As will be pointed out later the right to expense intangibles is as important to the American operator as the right to claim depletion allowance, and the loss of this right because of an inadvertent partnership classification might seriously affect the short term economics of a co-venture. ${ }^{11}$

\section{ORGANIZATION CLASSIFIED AS AN ASSOCIATION TAXABLE AS A CORPORATION}

The Code defines the term "corporation" to include associations." Unincorporated associations which under the Code fall within the classification of corporations are commonly referred to as "associations taxable as corporations."

The unincorporated "association" which is the cause for concern under the Code is the association of operating interests (working interests). The relationship between operating interests and non-operating interests (royalty interests) can be ignored. The association question does not involve this latter relationship. This is because the royalty interests have parted with their development rights forever, or at least for the period that the owners of the operating interests are entitled to develop the property. It is the owners of the operating interest who, in return for the largest share of production, alone are entrusted with the

i The ordinary attributes of a partnership such as sharing of income from joint marketing of production, mutual agency and unlimited individual liability are not present. There is a very limited delegation of authorlty to the operator and, beyond that authority, the operator has no authority to bind the other co-owners individually. See ss. 7-14 of the Alberta Partnership Act. R.S.A. 1955, c. 230, which deal with the relations of partners to persons dealing with them

* Under subchapter $\mathrm{K}$ the partnership does not itself pay income taxes but is a

computational and reporting device. Computation of income at the partnership level involves attributing the gross income to the partnership, as well as all deductions. including intangible drilling and development costs, depreciation. depletion. etc. The net income is distributed among the partners at the end of the fiscal year.

o An exception is the foreign tax credit election under s. $703(\mathrm{~b})$.

10 See supra, n. 6.

12 s. $7701(a)(3)$. 
business of developing the property and who risk the capital and supply the skill and labour necessary to carry on the business of development. Thus the operating and royalty in terests are not associates in the tax sense.

The association question does not pose a problem under the Income Tax Act of Canada. ${ }^{13}$ An unincorporated association in Canada possessing all the attributes of a corporation is not a taxable entity.

Classification of an operating agreement as an association taxable as a corporation under United States income tax law is generally undesirable because the revenue which is distributed by the association to the American operators is treated as dividend income from the association, and the American operators cannot claim as against this income the costs of drilling and development and the allowances for depletion and depreciation. The rationale is that it is the association, not the members individually, which incurs these costs and therefore only the association should be entitled to the income tax allowances.

In contrast to the taxation of associations and their members, the tax attributes of tenancies-in-common are more desirable. Under the Code, each American co-tenant reports his income or deducts his losses and expenses directly. He takes percentage or cost depletion and makes all elections individually. Of course, the amount of United States income tax paid by each co-tenant will depend on whether the co-tenant is an individual, corporation, trust, estate or partnership.

\section{ADMINISTRATIVE RULINGS-CLASSIFICATION OF JOINT OPERATING AGREEMENTS}

In 1948, after a number of judicial decisions had interpreted the meaning of "associations" under the Code, the Internal Revenue Service issued its now famous Revenue Ruling I.T. 3930. The Ruling constitutes the Internal Revenue Service's administrative and interpretive guide on how it will classify and treat a typical joint operating agreement for United States income tax purposes. The Internal Revenue Service will classify the agreement as one that creates either a partnership or an association taxable as a corporation, depending upon which of the two the organization more nearly resembles. The draftsman must be cautious about the extent to which he should rely on the guidelines set forth in the Ruling for avoiding association status. The Ruling gives guidance as to the income tax status of "operating agreements commonly used in the industry" only, and not to any particular form of operating agreement. The Internal Revenue Service has been careful to describe in the Ruling the "typical features" of provisions contained in "typical operating agreements". The draftsman should be further cautioned that the Ruling does not have the force of law, and merely represents the interpretation which the Internal Revenue Service will follow in classifying the arrangement made by the co-owners.

Because of the importance of the Ruling and the constant reference by American operators to its terms, and, because the ruling may not be readily available in publications or otherwise in Canada, the provisions of Revenue Ruling I.T. 3930 are set out herein in full:

Advice is requested with respect to the status for Federal income tax pur-

\footnotetext{
13 Income Tax Act, R.S.C. 1952, c. 148, hereinafter referred to as the "Income Tax Act".
} 
poses of joint operating agreements commonly entered into between co-owners of oil and gas properties or leaseholds.

An examination has been made of the provisions of typical operating agreements between parties having rights to exploit a particular property, several adjacent properties, or all of the properties comprising an oil and gas field. Operators' agreements (whether between co-owners of a lease on a single tract of land or between persons separately owning exploitation rights on adjoining tracts in the same oil field), though they differ in detail, generally contain similar essential provisions. Sometimes, where more than one tract is involved, there is an exchange of undivided interests by the owners of the working interests in the several tracts so that all owners have like undivided interests in each tract covered by the agreement. An operator, who need not be, but generally is, a co-owner, or becomes one at the time the contract is executed, is designated to take charge of the development and operation of the property or properties covered by the agreement. In general, such agreements contain the following typical features:

(1) The costs of development and expenses of operation are to be prorated among the parties in accordance with their respective interests.

(2) Division of the oil proceeds is usually accomplished by payment of the purchase price by the pipe-line company or other purchaser directly to the several parties in accordance with their respective shares as indicated by division orders signed by them. Generally, any party may take his share of the oil in kind. Where that right exists, any authority given the operator to market the oil may be revoked upon proper notice. Sometimes, however, the operator is authorized without qualification to market the product.

(3) The operator is required to carry adequate insurance and to make an accounting.

(4) Operating agreements remain in force until the mineral is exhausted or, in the case of unit operating agreements, for the terms of the lease or leases or renewals thereof. Sometimes an express provision is made for withdrawal of one of the parties by assignment of his rights to the others.

(5) The parties have voting power proportionate to their interests to choose and advise the operator (in cases in which only one lease is involved, broad powers are commonly vested in the operator named in the agreement) to change the operator, to determine drilling and operating plans, to audit and pass on the operator's accounting, and to pass on transactions for disposal of surplus equipment.

(6) Any party may sell or encumber his entire interest, but may not subdivide or sell without giving the others preferential option (in the case of agreements covering single leases, the contract may not contain express provisions to that effect).

(7) The liabilities of the parties are to be separate and not joint.

Such agreements, in the absence of provisions to the contrary, create mining partnerships which differ from general partnerships principally in that (1) they can arise only between joint operators, (2) they extend to and are terminated by exhaustion of the mineral deposit, (3) the majority in interest controls policies, and (4) the death of a participant or the transfer of his interest does not interrupt the relation-the heir or transferee becoming a participant. (See Mills and Willingham, Law of Oil and Gas (1926), Chapter XIX; Thornton, Oil and Gas (4th edition, 1925, volume 1, chapter XV; Summers, Oil and Gas (1938), volume 4, chapter 24.)

Mining operations carried on through the medium of a trust or a joint stock company, both of which are generally recognized as corporations under section 3797 of the Internal Revenue Code, are not considered herein. Nor is it intended in this ruling to explore the income tax status of any forms of operating agreements other than the above-described forms of operating agreements commonly used in the industry.

The definitions of the terms "partnership" and "corporation" in section 3797 of the Internal Revenue Code and corresponding provisions of prior revenue laws in effect classify any organization carrying on business, financial operations, or ventures for the joint profit of the associates as either a partnership or a corporation, depending upon which of the two it more nearly resembles. It thus appears that those group organizations which attain the corporate attributes of centralized management and continuity of life are associations taxable as corporations, but those which do not have such attributes are comprehended by the term "partnership". (See section 29.3797-2, Regulations 111). This rule is based upon the proposition that other corporate attributes, arising solely from 
the concept of separate personality or entity in the corporation, are generally recognized as unattainable by associations and, therefore, immaterial to classification as a corporation, since the statutory definition of the term "corporation" was manifestly intended to broaden that term to include associations serving a substantially similar function. Consequently, only continuity of life and centralization of control of group activities, the attributes of the corporate form of organization which may be commonly attained without incorporation, are regarded as material.

Pertinent court decisions support the above-mentioned rule in all essential particulars. (see Burk-Waggoner Oil Association v. Hopkins, 269 U.S. 110, T.D. 3790, C.B. V-1, 147 (1926); Morrissey et al., Trustees, v. Commissioner, 296, U.S. 344, Ct. D. 1064, C.B. XV-1, 264 (1936) ; Helvering v. Coleman-Gilbert Associates, 296 U.S. 369, Ct. D. 1067, C.B. XV-1, 261 (1936);Swanson et al., Trustees, v. Commissioner, 296 U.S. 362, Ct. D. 1065, C.B. XV-1, 270 (1936); Helvering v. Combs et al., Trustees, 296 U.S. 365, Ct. D. 1066, C. B. XV-1, 272 (1936); Bert, Trustee, v. Helvering, 92 Fed. (2d) 491; Commissioner v. North American Bond Trust et al., 122 Fed. (2d) 545, certiorari denied, 314 U.S. 701; Commissioner v. Fortney Oil Co. et al., and Commissioner v. Towline Oil Co., 125 Fed. (2d) 995; Commissionr v. Nebo Oil Co., Trust, 126 Fed., (2d) 148, certiorari denied, 317 U.S. 636; Wabash Oil \& Gas Association v. Commissioner, 160 Fed. (2d) 658, certiorari denied, 331 U.S. 843.) Read together, the cited opinions indicate that in order to classify an organization as an association taxable as a corporation (1) there must be associates, (2) the object of the organization must be joint profit, (3) there must be continuity of life, and (4) there must be centralized control of group affairs. Inasmuch as the first two requisites are generally recognized as elements common to all forms of business organizations, it seems clear that they form the essential test of associated, as distinguished from individual, enterprise but manifestly do not serve to distinguish between various forms of business organizations. (See Commissioner v. A. A. Lewis \& Co. et al., 301 U.S. 385, Ct. D. 1231, C.B. 1937-1, 232, which in effect holds there can be no association without associates.) It follows that under the statutory definitions in question all forms of unincorporated business organizations for joint profit are partnerships for income tax purposes except those organizations which, by attaining the continuity of life and centralization of management characteristic of the corporate form of organization, are by definition associations classifiable as corporations.

Applying the stated principles to the agreements in question and the rules governing mining partnerships which such agreements create, it seems clear that control is centralized in the majority interest or in the operator named to act for all. Also, as the life of such agreements is not interrupted by the death of a participant nor by the transfer of an interest, the organizations commonly created by such agreements have continuity of life. Furthermore, since the agreements are between at least two persons (the test that there must be associates thereby being met), the remaining question is whether the objective is joint profit.

Manifestly, profits arise not from mere extraction or from the processing of minerals, but from the sale thereof. Accordingly, it seems clear that if the joint objective is limited to development and the extraction and processing of minerals (at joint cost and expense to be met by contribution of the respective participants) for division in kind or for sale for the accounts of the several participants individually, the test of a joint venture for joint profit is not met. An organization created by such an agreement does not qualify as a corporation as defined in section 3797 (a) (3) of the Internal Revenue Code. As such agreements commonly allow the participants to take their shares of the mineral in kind (or provide for the sale of the shares of the respective participants for their individual accounts under revocable agency powers), the sale of the mineral, even though made by the operator, is a sale by. or on behalf of the individual participants. In such cases there is no joint profit contemplated or realized by the associates. That being true, such organizations may be classified for Federal income tax purposes as joint ventures or partnerships only in a qualified sense. Under I.T. 2749 (C. B. XIII-1, 99 (1934) and I.T. 2785 (C. B. XIII-1, 96 (1934) ), such joint operators are required to file qualified partnership returns showing only items of gross income and deduction. If such qualified partnership return were not required, it would be necessary for each of the joint owners to submit the same information by schedules attached to their individual returns.

For the reasons stated, in the case of operators' agreements in which the participants reserve the right to their shares of the oil in place (or the equivalent, i.e., the right personally to sell or direct the sale thereof for their benefit, or permit the operator to do so for them for the time being), it is held that 
the participants, through the partnership thus created, individually own depletable economic interests in the oil and gas in place and must report the proceeds therefrom as their income. On the contrary, where agreements irrevocably vest the operator in his representative capacity with the authority to extract and sell the mineral, there are created for income tax purposes associations taxable as corporations, which associations are the owners of the depletable economic interests in the oil and gas in place and of the income derived from operations.

In view of the foregoing, I.T. 2749, supra, and I.T. 2785, supra, are modified to accord with the conclusions reached herein. The Bureau, under those rulings, has consistently treated all such operating agreements as creating qualified partnerships, rather than associations, with the result that the participants therein have been taxed as individuals. Under authority contained in section 3791(b) of the Internal Revenue Code, this ruling will be applied only to taxable years beginning on or after January 1, 1949. Accordingly in the case of a joint operating agreement which creates an organization classifiable as an association under the principles contained herein, an amendment prior to January 1, 1949, to create an organization not so classifiable hereunder will avoid reclassification and treatment of such organization as an association under the Internal Revenue Code.

Inasmuch as this ruling pertains only to organizations created by those agreements commonly referred to as joint operating agreements, the nonretroactive application of this ruling does not relate to other forms of group organizations.

GEO. J. SCHOENEMAN,

Approved October 18, 1948.

Commissioner of Internal Revenue.

JOHN S. GRAHAM,

Acting Secretary of the Treasury.

Certain aspects of the Ruling should be particularly observed:

(a) The Ruling is not intended to explore the income tax status of any forms of operating agreement other than the form of operating agreements described in the Ruling which are "commonly used in the industry".

(b) In order to classify the operating agreement as an association taxable as a corporation the following requisites must exist;

(i) there must be associates,

(ii) the object must be joint profit,

(iii) there must be continuity of life, and

(iv) there must be centralized control of group affairs.

Requisites (i), (iii), and (iv) are present in the typical Canadian operating agreement. The agreement is made between at least two persons (the test that there must be associates thereby being met), and the life of the agreement is not interrupted by the death of a co-owner nor by the transfer of an interest (the test that there must be continuity of life thereby being met) and management and control of development operaions are centralized in the operator named to act for all of the co-owners (the test that there must be centralized control of group affairs thereby being met). ${ }^{14}$ The remaining question is whether the object of the organization is to make a joint profit. The object of the individual coowners is certainly to make a profit and the Ruling is clear that profits arise not from mere extraction or from the processing of minerals, but from the sale thereof. Accordingly, if the joint objective is limited to the development and extraction and processing of minerals (at joint cost and expense to be met by contributions of the respective co-owners)

14 Whether this test is met is arguable. Although Revenue Ruling I.T. 3930 states that the test is to apply in the case of typical operating agreements, the control vested in the operator in Canadian operating agreements is quite limited. much more so than is the control of directors of corporations with which the control of the operator is compared. 
for division in kind, or for the sale for the accounts of the several coowners individually, the joint profit test is not met and the organization, if any, created by the operating agreement does not qualify as an association taxable as a corporation. According to the Ruling, such organization may be classified for United States income tax purposes as a "joint venture or partnership only in a qualified sense".". So long as there is a division of the production in kind or for sale for the account of each individual co-owner in the organization (as opposed to a division or sale for the organization's joint account) the test of a joint profit is not met.

In 1949, the Internal Revenue Service issued Revenue Ruling I.T. 3948 as a "clarification of I.T. $3930 \ldots$. . relative to the status for Federal income tax purposes of joint operating agreements commonly entered into between co-owners of oil and gas properties." The specific purpose for its issuance is set out in the first paragraph of the Ruling. For the reasons that Revenue Ruling I.T. 3930 was quoted in full above, the later Ruling is set out herein in full:

Advice has been requested respecting the application of I.T. 3930 (C.B. 1948-2, 126) in cases (1) where the operator or some other person is, by the terms of the operating agreement or by separate contract, given the contractual right or the option to purchase some or all of the oil and gas produced from the jointly operated properties; (2) where there are outstanding contracts which will dispose of oil and gas produced by the joint operation in taxable periods extending beyond the effective date of I.T. 3930, as extended by I.T. 3933

(C. B. 1948-2,130) to the first day of a taxable year beginning on or after July 1, 1949; and (3) of contracts entered into by an agent (authorized to act for the time being only) for the sale of oil or gas for periods of time regarded by the industry as minimum commitments under the circumstances.

I.T. 3930, supra, treats joint operating agreements commonly entered into between co-owners of the oil and gas properties as creating associations taxable as corporations under the Internal Revenue Code only if such agreements create organizations with a joint profit objective. That is, organizations created by such agreements are considered corporations if some person or persons are irrevocably authorized to act in a representative capacity for a fixed or determinable period of time to sell the production from the joint operation for the joint account of two or more of the co-owners. Thus, the test of an association in such cases is therefore essentially organizational, depending upon the existence of collective irrevocable representative capacity which, arising from the irrevocable vesting of authority in one representative (including cases where such representative capacity is vested jointly in more than one person) to market the oil and gas produced from the jointly operated properties for two or more co-owners, marks an organization with a joint profit objective. Association status turns upon the existence of such collective irrevocable representative capacity. Consequently, where such capacity exists, classification as an association under the Internal Revenue Code may be avoided only if such capacity is withdrawn prior to the first day of a taxable year beginning on or after July 1,1949, the effective date of I.T. 3930. Moreover, where such withdrawal is timely, no modification of sale or option contracts entered into prior to such effective date is necessary.

A co-owner who reserves the right to take his share of the production in kind, or to direct its sale,-may contract to sell or grant options to purchase his share as he sees fit without creating an association taxable as a corporation for Federal income tax purposes. Representative capacity under I.T. 3930 is not involved in such case. Also, the fact that some or all of the co-owners execute identical contracts, or the same instrument, with the same purchaser or optionee, each thereby contracting to sell all or any fractional part of his own share, or to grant options to buy any fractional part of such share, will not be held as achieving a different tax consequence since obviously no representative capacity is involved. Each owner in such a case has exercised his own business discretion.

It seems equally clear that one co-owner may authorize a person or persons (so long as that person or persons is not another co-owner who is also selling

15 Note that the partners can elect to be excluded from the partnership tax rules in subchapter $K$ of the Code by a proper election under section 761 (a) thereof. For a discussion of such an election, see pp. 199-201, below. 
his share of the production) to sell his individual share of the production, or to grant options as respects such share, without creating an association taxable as a corporation. Such representative capacity, even though irrevocable, (1) does not involve an authorizalion to act jointly fo: more than the one co-owner, (2) does not indicate a joint profit objective, and (3) is deemed the equivalent of a personal exercise of his own business discretion by the one co-owner. However, under I.T. 3930, the same representative or representatives may not act for more than one of the co-owners (including himself) without creating an association taxable as a corporation as respects the c:-owners so represented, unless such authorization is for the time being only (i.e., revocable at will), because, in such a case, collective irrevocable representative capacity indicative of an organization with a joint profit objective would be present.

There remains for clarification the limitations inherent in the distinction drawn in I.T. 3930 between revocable representative capacity (authority to act for more than one co-owner for the time being) and collective irrevocable representative capacity (authority to act for more than one co-owner including himself). As an association, like a formal corporation, may be organized for a short as well as a long period of time, revocable representative capacity must be terminable at will to avoid the formation of an association with a joint profit objective. However, an agent may find it desirable or necessary to enter into sale or option contracts for an extended period of time rather than to market production on a day-to-day besis. For instance, to state an extreme example, in cases of certain cycling operations, it is necessary to contract for production for a minimum period of one year. Accordingly, discretionary authority terminable at will granted to a person or persons representing two or more co-owners to enter into contracts committing the principals for such reasonable periods of time as are consistent with the minimum needs of the industry under the circumstances, but not to exceed one year, will not be regarded as inconsistent with revocable representative capacity in the sense that the term is used herein and in I.T. 3930. Of course, as pointe dout above, the co-owners acting for themselves as principals may enter into such contracts for indefinite periods, as such action does not involve collective irrevocable representative capacity.

The fundamental concern of the petroleum industry in the United States which gave rise to Revenue Ruling I.T. 3948 was the extent to which one of the co-owners, usually the operator, could act in a representative capacity in disposing of the production owned by each of the other co-owners. In Revenue Ruling I.T. 3948 the Internal Revenue Service stated that the status of the organization, not otherwise taxable as a corporation, is not altered by the operator or any other co-owner, acting in a representative capacity, selling or otherwise disposing of each co-owner's share of production for short periods, so long as the selling arrangements made between the operator and the purchaser are cancellable at will by the owner of the production and do not exceed a period of one year. The actual words of the Ruling are:

Accordingly, discretionary authority terminable at will granted to a person or persons representing two or more co-owners to enter into contracts committing the principals for such reasonable periods of time as are consistent with the minimum needs of the industry under the circumstances, but not to exceed one year, will not be regarded as inconsistent with revocable representative capacity in the sense that the term is used herein and in I.T. 3930. Of course, as pointed out above, the co-owners acting for themselves as principals may enter into such contracts for indefinite periods, as such action does not involve collective irrevocable representative capacity. (Emphasis added.)

In summary, the essence of the Rulings is this:

(a) if each co-owner has the right to take in kind or separately dispose of its share of the production then a corporation for United States income tax purposes does not exist, or,

(b) if the operator has only revocable authority terminable at will in its representative capacity to market the production for two or more co-owners, a corporation for United States income tax purposes does not exist, and

(c) the operator will not be considered to have revocable authority if 
it may market for two or more co-owners for periods of time consistent with the minimum needs of the industry, but not longer than one year.

\section{E. DRAFTING OF JOINT OPERATING AGREEMENTS}

The foregoing considerations should serve as a general background in approaching the drafting of joint operating agreements from the standpoint of American income tax law. With the understanding that the primary tax problem is organizational, a few guide posts can be established to assist the draftsman. The objective will be to avoid creation of an operating agreement partnership or association with corporate features and to preserve the identity of the co-owners as tenants-incommon.

In preparing a typical Canadian joint operating agreement, the draftsman should do the following:

(1) Provide for the disposal of production in accordance with Revenue Rulings I.T. 3930 and I.T. 3948;

(2) provide for exclusion of the "organization" from the partnership taxation provisions of Subchapter $\mathrm{K}$ of the Code;

(3) restrict the joint objective to development, extraction and processing, and avoid joint marketing of production and other activities which have as their principal purpose cycling, manufacturing, or processing for persons who are not parties to the operating agreement; and

(4) preserve the separate status of the co-owners as tenants-incommon.

1. Provision for the Disposal of Production in Accordance with Revenue Rulings I. T. 3930 and I.T. 3948

One of the two most important tax provisions contained in the operating agreement is the so-called "disposal of production" clause. The disposal of production clause, apart from its non-tax aspects, should be designed with regard to the provisions of Revenue Rulings I.T. 3930 and I.T. 3948. It will be recalled that in Revenue Ruling I.T. 3930 the Internal Revenue Service stated that:

As such agreements commonly allow the participants to take their shares of the mineral in kind (or provide for the sale of the shares of the respective participants for their individual accounts under revocable agency powers), the sale of the mineral, even though made by the operator, is a sale by or on behalf of the individual participants. In such cases there is no joint profit. . . . ... where agreements irrevocably vest the operator in his representative capacity with the authority to extract and sell the mineral, there are created for income tax purposes associations taxable as corporations. . . .

In drafting a suitable disposal of production clause, two matters should be kept in mind for United States taxation purposes. The disposal of production clause must provide that:

(a) each party has the right to take in kind or separately dispose of its share of production, and

(b) the authority of the operator to sell a party's share of production must

(i) be revocable at the will of the party, and

(ii) the term of the sales contract executed by the operator and purchaser for sale of the party's share of production shall 
be, in the words of Revenue Ruling I.T. 3930, "for such reasonable periods of time as are consistent with the minimum needs of the industry under the circumstances, but not to exceed one year. ..."

In most Canadian operating agreements, the right of a participant to take its production in kind or separately dispose of it presents no difficulty and Canadian operators have accepted the disposal of production clause because they prefer to have a call upon their own production for reasons quite apart from income tax considerations. However, the United States income tax purpose in giving each party this right is that in the absence of a contrary provision the operator may, subject to its obligation to account to the participant, ${ }^{16}$ sell the participant's production under sale contracts with terms exceeding the minimum needs of the industry or one year, in which case, the operating agreement would be an association taxable as a corporation, and the exclusion privilege in subchapter $K$ of the Code would be unavailable because the operating agreement would not meet the requirements of Regulation 1.761-1 (a) (2) (iii) (b).$^{17}$

I might however point out some problems which arise in connection with drafting the disposal of production clause to comply with Revenue Rulings I.T. 3930 and I.T. 3948.

\section{(a) Revocation at Will.}

Difficulties arise occasionally over inclusion in the disposal of production clause of the right of a party to terminate "at will" the authority given to the operator to sell its production. Canadian operators often express concern that the usual sales contract to be terminated requires prior notice to the purchaser, usually 30 days, and the party's right to terminate at will the operator's authority conflicts with the operator's right to terminate the sales contract. Revenue Ruling I.T. 3948 provides that "revocable representative capacity must be terminable at will to avoid the formation of an association with a joint profit objective." Therefore, the agreement should not contain provisions that such representative capacity may be revoked on 30 days' notice or some similar term. The simple and effective solution to the matter is to provide that the participant may at will terminate the operator's authority, but may take its share of production in kind only upon the expiration of the current sales contract. ${ }^{18}$

(b) Term of Sales Contracts.

Canadian operators have experienced no serious difficulty in the one year maximum term limitation in sales contracts. A possible explanation for the one year limitation may be found in Revenue Ruling I.T. 3948 where it is stated that:

... an agent may find it desirable or necessary to enter into sale or option contracts for an extended period of time rather than to market production on a day to day basis. For instance, to state an extreme example, in cases of certain cycling operations, it is necessary to contract for production for a minimum period of one year. Accordingly, ... contracts . . not to exceed one year, will not be regarded as inconsistent with revocable representative capacity in the sense that term is used herein and in I.T. 3930.

16 See Olisa, Legal Problems Arising out of Co-ownership of Oil and Gas Leasehold Estate and Facilities, supra, pp. 177-86.

1: See pp. 199, 202-3, below.

is See clause 705, Model On and Gas Unit Agreement, approved at the 25th Mines Ministers Conference, 1968. 
In disposing of production other than crude oil, the co-owners arrange separate sale contracts and the operator merely delivers to each coowner's purchaser the share of production due.

To avoid the association question, and notwithstanding the absence of serious operating problems, the disposal of production clause should also restrict the operator's authority to enter into sales contracts for "such reasonable periods of time as may be consistent with the minimum needs of the industry under the circumstances." This language is suggested by Revenue Ruling I.T. 3948. Some Canadian operating agreements $^{19}$ do not employ the exact language of Revenue Ruling I.T. 3948 but substitute "minimum term obtainable" for "such reasonable periods of time as are consistent with the minimum needs of the industry under the circumstances." I am unsure whether there has been a determination in the United States of what is meant by "minimum needs of the industry under the circumstances," and I am unsure whether it is equivalent to the "minimum term obtainable," or other variations that are used in Canada. In fact "minimum term" and "minimum needs" may be different, depending on the locality and the conditions existing at the time the sales contract is executed. The language of Revenue Ruling I.T. 3948 has acquired universal acceptance in the United States and very wide acceptance in Canada. No serious operating or disposal of production problems have resulted from its use. Suffice it to say that although there are many ways in which the concept may be expressed, employment of the literal text of Revenue Ruling I.T. 3948 is the best and safest way to approach the drafting problem of qualifying under a tax relief provision.

(c) Pricing Provision.

The revocable authority of the operator to sell a party's share of production probably imposes no positive duty on the operator to do anything beyond making sales at the going price. Any arrangement between participants to share markets would place the non-association status in jeopardy. However, there is no objection to including a pricing provision in the following form:

Operator shall have the right to dispose of a party's share of production at the same price and on the same terms as operator receives for its own share or at such price as operator, acting reasonably and prudently, and having regard to current market prices, availability of markets and economic conditions affecting the petroleum industry generally, would dispose of its own share of such production.

Inclusion of the pricing provision is entirely optional so far as the Revenue Rulings are concerned, but it would seem advantageous to the non-taking participant and equitable for the taking participant to include it. ${ }^{20}$

19 Id.

:I An example of a Disposal of Production Clause is the following:

"Each party shall own and at its own expense take in kind or separately dispose of Its share of the petroleum substances produced from wells operated for the joint account after deduction therefrom of its share of the petroleum substances unavoidably lost or used in development and producing operations on the joint lands and in preparing and treating petroleum substances for marketing purposes. If, and for so long as, Non-Operator fal!s to take in kind or separately dispose of its share of the petroleum substances as produced. or if it so directs Operator. Operator shall have the right to dispose of Non-Operator's share of the petroleum substances at the same price and on the same terms as Operator receives for its own share of such petroleum substances or at such price as Operator, acting as a reasonably prudent Operator, and having regard to current market prices, availability of markets and economic conditions affecting the petroleum industry 
2. Provision for Exclusion of the "Organization" from the Partnership Taxation Provisions of Subchapter $K$ of the Code

For the reasons mentioned above, parties to joint operating agreements usually agree that the operating agreement is not a partnership agreement and the provisions of subchapter $K$ of the Code are not to apply to the joint operations. To give effect to this agreement of the parties a formal election to exclude the joint operations from the application of subchapter $K$ of the Code must be executed and filed. The enabling provision is section 761 (a) of the Code which provides:

PARTNERSHIP-For purposes of this subtitle, the term "partnership" includes a syndicate, group, pool, joint venture, or other unincorporated organization through or by means of which any business, financial operation, or venture is carried on, and which is not, within the meaning of this title [subtitle], a corporation or a trust or estate. Under regulations the Secretary or his delegate may, at the election of all the members of an unincorporated organization, exclude such organization from the application of all or part of this subchapter, if it is availed of-

(1) for investment purposes only and not for the active conduct of a business, or

(2) for the joint production, extraction, or use of property, but not for the the purpose of selling services or property produced or extracted,

if the income of the members of the organization may be adequately determined without the computation of partnership taxable income.

Any question of whether the typical Canadian operating agreement constitutes an "unincorporated organization" under section 761 (a) should be answered by the Regulations which are attendant to the section. Section 1.761-1(a) (2) of the Regulations makes it clear that an "unincorporated organization" includes an operating agreement. It provides that an "unincorporated organization described in subdivision ... (iii) . . . may be excluded from the application of . . subchapter K. . . ."Subdivision (iii) provides:

(iii) Operating agreements. Where the participants in the joint production, extraction, or use of property-

(a) Own the property as coowners, either in fee or under lease or other form of contract granting exclusive operating rights, and

(b) Reserve the right separately to take in kind or dispose of their shares of any property produced, extracted, or used, and

(c) Do not jointly sell services or the property produced or extracted, although each separate participant may delegate authority to sell his share of the property produced or extracted for the time being for his account, but not for a period of time in excess of the minimum needs of the industry, and in no event for more than one year, then

such group may be excluded from the application of the provisions of subchapter $K$ under the rules set forth in subdivision (iv) of this paragraph. However, the preceding sentence does not apply to any unincorporated organization one of whose principal purposes is cycling, manufacturing, or processing for persons who are not members of the organization.

It should be emphasized that the "organization" makes the election, not the individual members; but all members of the organization must agree to the election before it is available. This requirement is mandatory and, although the Regulations do not require it, a specific statement of this agreement and the authority of one of the parties to execute

generally, would dispose of its own share of such petroleum substances. Operator may in such case enter into any contract for the disposition of the petroleum substances but any such contract shall be only for such reasonable period of substances but any such contract shall be only for such reasonable period of time as is consistent with the minimum needs of the industry under the circumstances and in no event shall the term thereof exceed one year. Subject to such
contract Non-Operator may commence or resume taking its share of petroleum substances in kind at any time. If Operator does not dispose of Non-Operator's share of petroleum substances. Non-Operator shall, at its own expense, provide facilities for the taking thereof." 
and file the return should be included in the operating agreement to avoid dispute or disagreement that the election was not made or that the operator was not authorized to file evidence of the election.

Regulation 1.761-1(a) (2) (iv) requires the organization to make the election "in a statement attached to a properly executed partnership return, Form 1065." Either the operator or any one of the parties may file the return and usually one of the American parties assumes the responsibility. Form 1065 is left incomplete except for the name or other identification and the address of the organization. The statement attached to the return includes:

(a) the names and addresses of all the members of the organization;

(b) a statement that the organization qualifies for exclusion under the provisions of Regulation 1.761-1(a) (2) (i) and (iii);

(c) a statement that all of the members of the organization elect that it be excluded from all of subchapter $K$; and

(d) a statement indicating where a copy of the agreement under which the organization operates is available (or if the agreement is oral, from whom the provisions of the agreement may be obtained).

Some Canadian operators who do not file income tax returns in the United States evidence concern"1 about the form of the partnership clause and insist that the statutory mandate in section 761 (a) be ignored and that the election be made by those members only "who are subject to the income tax laws of the United States". This assumes that the Internal Revenue Service will apply a less strict interpretation of the words "all the members" when reviewing Canadian operating agreements than when reviewing similar agreements in the United States. The Internal Revenue Service has published no ruling supporting this view, although one may suspect that some Internal Revenue District Offices in which the statement of the election is filed are more indulgent than others and have ignored improper elections.

The importance of a complete and proper election cannot be overstated. Its purpose is to secure for each party individually its proportionate interest in deductions for intangible drilling and development costs and in allowable depletion, rather than have such deductions accrue to the organization as a partnership.

21 Under the Reciprocal Tax Convention between Canada and the United States (which is entitled Convention and Protocol between Canada and the United States of America for the Avoidance of Double Taxation and the Prevention of Fiscal Evasion in the Case of Income Taxes), it is clear the United States does not tax the income of foreign corporations (Canadian companies) except from sources within the United States, and then only the industrial and commercial profits of permanent establishStates, and then only the industrial and commercial profits of permanent establish-
ments of the Canadian company within the United States (See Article II for a definition of "industrial and commercial profits"). Article I provides as follows:

"An enterprise of one of the contracting States is not subject to taxation by the other contracting state in respect of its industrial and commercial profits except in respect of such profits allocable in accordance with the Articles of this Convention to its permanent establishment in the latter state."

United States Regulation T.D. 5206 relates to the taxation of non-resident allen individuals, residents of Canada, and Canadian corporations under the Tax Convention. It recites section 22 of the 1939 Code as follows:

"The following items shall not be included in gross income and shall be exempt from taxation under this chapter: included in gross income and shall be exempt from taxation under this chapter: $\dot{1}$ (7) Income of any kind, to the extent
required by any treaty obligation of the United States:" [This provision has been carried forward in the present Code in section 894 (a) and (b).]

Paragraph 519.102(b) of the Regulation provides that:

"The specific classes of income from sources within the United States which are exempt by reason of the convention from United States income taxes are (1) Industrial and commercial profits of a Canadian enterprise having no permanent establishment in the United States (Article I);" 
To ensure that the Canadian parties to the operating agreement, who do not file an income tax return in the United States, and who do not wish to become involved in any way with the United States taxing authorities, achieve this end, and to ensure that the election under section 761 (a) to exclude the operating agreement organization from the partnership taxation provisions of subchapter $K$ of the Code is effective, the following provision (or one of like effect) should be included in the operating agreement:

The parties hereto agree that if for purposes of the United States Internal Revenue Code of 1954 this agreement or the relationship established thereby constitutes a partnership, as defined in section $761(a)$ of the said Code, each of the parties hereto who are entitled under the said section 761 (a) to elect, hereby elect to have the said partnership excluded from the application of subchapter $\mathbf{K}$ of chapter 1 of subtitle $A$ of the said Code, or such portion thereof as the Secretary of the Treasury of the United States or his delegate shall permit by election to be excluded therefrom. Operator ${ }^{22}$ is authorized to execute such election on behalf of the parties who are entitled to make such election and to file the election with the proper United States government office or agency, and operator is further authorized and directed to execute and file such additional or further evidence of such election as may be required.

As stated above, the importance of the section 761 (a) election is to permit the co-owners who bear the cost of drilling wells to expense their share of the intangible drilling and development costs. However, if the co-owners fail to make a proper election to be excluded from the partnership taxation provisions of subchapter $K$ of the Code their right to expense the intangible costs is lost and the partnership may expense such cost only if it has elected to do so. Apparently anticipating the results of an improper or unacceptable election, some operators in the United States take the precaution of drafting into operating agreements the following kind of clause:

If for any reason the operating agreement or operations thereunder constitute a partnership then it and all the parties thereto do elect to expense all intangible drilling and development costs.

Canadian operating agreements do not usually include this provision. However, where the right to expense intangibles is an important consideration the participants should consider the need to include it. Accompanying such a provision should be authority in the operator or party concerned to execute and file whatever related elections are required by the Internal Revenue Service.

\section{Restriction of the Joint Objective to Development, Extraction and Processing.}

The Internal Revenue Service has stated in Revenue Ruling I.T. 3930 that:

Manifestly, profits arise not from mere extraction or from the processing of minerals but from the sale thereof. Accordingly, it seems clear that if the joint objective is limited to development and the extraction and processing of mineral (at joint cost and expense to be met by the contributions of the respective participants) for division in kind or for sale for the accounts of the several participants individually, the test of a joint venture for joint profit is not met. An organization created by such an agreement does not qualify as a corporation. ...

The draftsman should avoid giving the operator or any party irrevocable authority to sell another party's production and should limit to a

22 The name of one of the parties, preferably one who files an income tax return in the United States and is a responsible party, may be substituted for operator. 
period of one year, or a shorter period if the minimum needs of the industry permit, the operator's revocable authority to sell another party's share of production. Involvement with the association question will thereby be avoided.

Regulation 1.761-1(a) (2) (iii) ${ }^{23}$ under section 761 (a) of the Code incorporates the salient features of Revenue Rulings I.T. 3930 and I.T. 3948 and permits the unincorporated organization to be excluded from the partnership taxation provisions of the Code, but such exclusion does not apply to an unincorporated organization, "one of whose principal purposes is cycling, manufacturing, or processing for persons who are are not members of the organization". (Emphasis added.)

In respect to subchapter $K$ election, ${ }^{24}$ care should be taken by the draftsman that the operating agreement conforms strictly to the provisions of Regulation 1.761-1(a) (2) (iii), and in particular, does not provide to the parties the right to "jointly sell services or the property produced or extracted" or provide that one of its "principal purposes is cycling, manufacturing or processing" for outsiders.

Unfortunately, this Regulation strikes squarely at an important aspect of the natural gas industry in Canada. In the case of gas processing plants the plant owners often must consider whether to offer use of the plant capacity for processing outside gas, i.e., gas not owned by the plant owners. ${ }^{25}$ Indeed they may be compelled to process such outside gas. ${ }^{2 n}$ The contractual arrangements made to process outside gas vary with the circumstances. However, they usually take one of the two forms. Either the outside gas is processed for a fee ${ }^{27}$ and the resulting residue gas liquids and plant products are delivered to the owner or its nominee, or the outside gas is purchased ${ }^{28}$ by the plant owners prior to processing.

If the outside gas is processed in the plant for and at the expense of the owner of the outside gas, and if processing of outside gas constitutes one of the principle purposes of the plant, the plant owners would not be entitled to exclusion from the partnership provisions of subchapter $K$ of the Code. The Internal Revenue Service has provided no guidelines as to what is meant by "principle purpose" in Regulation 1.761-1(a) (2) (iii). Some persons in the industry are of the view that

23 Supra, p. 199.

24 Permitted under s.761 (a) of the Code which is set out on p. 199, supra.

2: The discussion herein with respect to gas processing plants applies equally to other facllities such as water plants, flowlines, tank batteries, salt water disposal facilities which are owned by certain parties and the use of which is commonly desired by persons other than the owners.

20 The Oil and Gas Conservation Act, S.A. 1969, c. 83, s. 54. The fact that the organization might be processing outside gas under compulsion from the Alberta Oil and Gas Conservation Board is not a defence to a move by the Internal Revenue Service classifying the organization as an association for United States income tax purposes. However, there probably is a good chance that the American participant who was "voted in" or is placed in the position of being declared a common processor under the Act (provided that the joint operating agreement did not specifically contemplate such an eventuality) would generally receive more sympathetic treatment than one such an eventuality

27 The fee would normally Include recovery of operating and overhead charges plus a profit. Obviously the Canadian participants who are not concerned with United States income tax law would favour this arrangement, since they would start from the proposition that they are in business to make money, and if the processing of gas tendered to them by an outsider will yield a profit. this is what they want to do. The possible alternative arrangements of a purchase of the outside gas or a common processor order under the Oil and Gas Conservation Act are poor alternatives by comparison.

28 The purchase price might be the average price per Mcf of residue gas paid to the members, less plant operating and overhead charges. Purchasing outside gas may be impractical, however, if the arrangement is inconsistent with gas sales commitments of the outside owner. Further, this kind of arrangement is complicated and may be unattractive to the Canadian operator. 
use of 10 per cent or even 20 per cent of plant capacity for processing gas would be considered as merely incidental to the principal purpose of the plant, i.e., processing of gas owned by the plant owners, and the subchapter $\mathrm{K}$ election would be available.

In Canada it is unusual for plant owners or unit owners to build and operate a processing or manufacturing plant for the principal purpase of cycling, manufacturing, or processing outside gas. Consequently, in the usual circumstances the election under subchapter $K$ will be available even where some gas is processed for non-plant owners.

With respect to the association question and processing of outside gas for a fee, the Internal Revenue Service has given no guidelines with respect to the permissible use of a gas plant or other jointly owned facilities for the benefit of non-owners. It has, however, indicated in private rulings in the United States, that it will not raise the joint profit issue, if a real effort is made by the plant owners to process outside gas at actual cost, and if the service is minor in nature or merely incidental to the principal purpose of the plant owners. A practical consideration to be made by the Internal Revenue Service is whether the United States treasury would materially benefit from classifying the plant as an association taxable as a corporation. These are subjective tests which would be applied by the Internal Revenue Service in light of the facts and circumstances of a given case.

If the raw outside gas is purchased by the plant owners before it is processed in the gas plant, it is doubtful that the plant owners can be said to be manufacturing liquids and sulphur or processing natural gas "for persons who are not members of the organization". In this case, the argument that most likely would be put to the Internal Revenue Service is that the purchased outside gas is no different from the gas produced and owned by the members and only gas owned by the members is being processed in the plant. Consequently, the subchapter $K$ election would be available and, as no joint profit objective exists, the association question would not be raised.

Because of possible involvement with the association question and the real concern that processing of outside gas may render the election under subchapter $\mathrm{K}$ of the Code unavailable, the American operator prefers, where there is a possibility of involvement with owners of outside gas, to keep processing and manufacturing functions separate from unit or other development operations. ${ }^{29}$

\section{Preservation of the Separate Status of the Co-owners as Tenants- in-Common}

The draftsman's objective in avoiding the creation of an operating agreement partnership or association taxable as a corporation is to pre-

20 The decision to separate functions has United States income tax implications as well. If the plant processes gas from leases which are owned only by the plant owners the revenue from those plant operations, which is related to the producing as opposed to the manufacturing process in the plant, may be allocated to the leases for depletion purposes. On the other hand, the risk of not separating the functions is that if the plant owners are declared to be an association, the association status would extend to the entire venture, thereby resulting in extremely unfavourable tax consequences from the wellhead to the market place. 
serve the separate status of the co-owners as tenants-in-common. ${ }^{30}$ This relationship is desirable for purposes other than tax law and Canadian operators do not object to it.

To create $^{31}$ and preserve the tenancy-in-common relationship, the joint operating agreement should contain express provisions that:

(a) There is an intent to create the relationship of tenants-in-common and not an association, partnership, joint venture or other organization or legal relationship. A suitable provision is as follows:

The parties shall hold the [property] as tenants-in-common and nothing in this agreement shall be construed as creating a partnership of any kind, joint venture, association, or trust among the parties or an organization of any kind, nor do the parties intend that the activities under this agreement constitute a business, financial operation or venture. In the United States, as in Canada, the nature of the relationship is a question of fact to be determined from the circumstances of the case. However, where the intent of the parties becomes a critical determinant, the self-serving statement of their intent may be of some value. The last two lines of the above quoted clause are included to avoid the related provision in section 761 (a) of the Code.

(b) Each participant owns a percentage undivided interest in all the property, including the documents of title, land and other property (real or personal) associated with the joint operations. This provision is particularly important because Regulation 1.761-1 (a) (2) (iii) (a) requires that the parties own "the property as co-owners either in fee or under lease or other form of contract granting exclusive operating rights" before the election under section 761 (a) of the Code is available.

(c) Each party is separately liable for its proportionate share of the costs of development and operating expenses of the joint operations, liability to third parties, payment of the royalties and other payments due to the non-operating interests. This provision should be included because it emphasizes the individual nature of the arrangements and reduces its organizational characteristics.

(d) Each party's liability is not joint or several, but each party is separately liable to the extent of its undivided interest. This provision creates limited liability, a characteristic associated with corporations, but its obvious advantages far outweigh any risks it may have in a consideration of the association in question.

In typical Canadian unitization and plant operating agreements the concept of an "operating committee" has been introduced. The operating committee usually consists of voting representatives of all the participants who by majority vote, supervise and control development, producing and processing operations. The American participant must avoid

30 In discussing tenancy-in-ccmmon, Anger and Horsberger, Law of Real Property (1959). state at pp. 187-88 that "there -is only one necessary unity-the unity of possession-it being unnecessary that there be unity of title, unity of interest or unity of time of vesting of the estates. The occupation of tenants-in-common is undivided and none can claim a separate part except by partition."

31 Id., at 188. The authors state that "there are only two ways of creating a tenancyin-common-either by limiting the estate to grantees expressly as tenants-in-common or by limiting to each grantee an undivided part." 
involvement with permanent operating committees composed of representatives of less than all participants. Such operating committees possess the characteristics of a corporate board of directors and centralized control of the parties' operations, which is one of the principal characteristics of a corporation mentioned in I.T. 3930.

The American participant prefers to avoid any reference to, or use of, "operating committees" in joint operating agreements. However, because the concept has gained wide acceptance in typical unitization ${ }^{32}$ and plant operating agreements in Canada, the American participant seldom has any choice in the matter. He may; however, enter into "operating committee agreements" without great risk of involvement with Revenue Ruling I.T. 3930 and the association question if the operating committee is not unchangeable, is composed of representatives of all the parties, and is established by a provision as follows:

The parties shall supervise and control [operations] through an operating committee composed of their duly appointed representatives. Each party shall as soon as possible notify operator of the name and address of its representative and one or more alternate representatives who are authorized to represent and bind the party with respect to [operations]. A party may change any of its representatives from time to time by notice to operator. Two or more participants may appoint the same person as their representative who shall cast a separate vote for each of his principals.

This provision has been readily adopted by Canadian operators. ${ }^{33}$

\section{F. PROVISIONS RELATING TO INTANGIBLE DRILLING AND DEVELOPMENT COSTS}

An important United States income tax provision which Canadian draftsmen encounter occasionally is section 263 (c) of the Code which relates to intangible drilling and development costs in the case of oil and gas wells. Section 263 (c) provides that:

Intangible Drilling and Development Costs in the case of Oil and Gas Wells. $\ldots$ regulations shall be prescribed ... which ... [grant] ... the option to deduct as expenses intangible drilling and development costs in the case of oil and gas wells. ...

Section 263 (c) is the enabling provision which permits intangible drilling and development costs ${ }^{34}$ incurred by an operator in the development of oil and gas properties to be capitalized or expensed at the operator's option. ${ }^{3 i}$ This right may be characterized, along with the depletion allowance, as one of the most valuable rights accorded the oil and gas operator under the Code. Many, if not most, American operators who qualify under section 263 (c) elect to expense rather than capitalize the intangibles. This is because the operator can write off his intangibles at the present and invest his immediate tax savings in new ventures, thus providing an incentive for the development of new petroleum reserves.

In order for the operator to qualify under section 263 (c) and be entitled to exercise the option to expense intangibles, he must comply

32 See Clause 401. Model Oil and Gas Unit Operating Agreement, approved at the 25th Min.

33 Id. ines Ministers Conference. 1968.

34 These costs are referred to hereinafter as "intangibles".

See Regulation 1.612-4(b) and (d). If intangibles are expensed they can be deducted immediately. If they are capitalized, they are recovered through depletion. The
option is available in Canada if the American operator is required to report income for United States income tax purposes. (Rev. Bull. 67-34; 1967-1 C.B. 72). 
with the rules set forth in Regulation 1.612-4(a) which are set out herein in full:

(a) Option with respect to intangible drilling and development costs. In accordance with the provisions of section $263(\mathrm{c})$, intangible drilling and development costs incurred by an operator (one who holds a working or operating interest in any tract or parcel of land either as a fee owner or under a lease or any other form of contract granting working or operating rights) in the development of oil and gas properties may at his option be chargeable to capital or to expense. This option applies to all expenditures made by an operator for wages, fuel, repairs, hauling, supplies, etc., incident to and necessary for the drilling of wells and the preparation of wells for the production of oil or gas. Such expenditures have for convenience been termed intangible drilling and development costs. They include the cost to operators of any drilling or development work (excluding amounts payable only out of production or gross or net proceeds from production, if such amounts are depletable income to the recipient, and amounts properly allocable to cost of depreciable property) done for them by contractors under any form of contract, including turnkey contracts. Examples of items to which this option applies are, all amounts paid for labor, fuel, repairs, hauling, and supplies, or any of them, which are used(1) In the drilling, shooting, and cleaning of wells,

(2) In such clearing of ground, draining, road making, surveying, and geological works as are necessary in preparation for the drilling of wells, and

(3) In the construction of such derricks, tanks, pipelines, and other physical structures as are necessary for the drilling of wells and the preparation of wells for the production of oil or gas.

In general, this option applies only to expenditures for those drilling and developing items which in themselves do not have a salvage value. For the purpose of this option, labour, fuel, repairs, hauling, supplies, etc., are not considered as having a salvage value, even though used in connection with the installation of physical property which has a salvage value. Included in this option are all costs of drilling and development undertaken (directly or through a contract) by an operator of an oil and gas property whether incurred by him prior or subsequent to the formal grant or assignment to him of operating rights (a leasehold interest, or other form of operating rights, or working interest); except that in any case where any drilling or development project is undertaken for the grant or assignment of a fraction of the operating rights, only that part of the costs thereof which is attributable to such fractional interest is within the option. In the expected cases, costs of the project undertaken, including depreciable equipment furnished, to the extent allocable to fractions of operating rights held by others, must be capitalized as the depletable capital cost of the fractional interest thus acquired.

A number of points in the Regulations should be observed:

(a) "Intangibles" include wages, fuel, repairs, hauling, supplies, etc., incident to and necessary for the drilling of wells and the preparation of wells for the production of oil and gas. Generally speaking, these are items which have no salvage value.

(b) The option to capitalize or expense is available with respect to intangibles incurred by the operator.

(c) An "operator" is one who holds an operating interest, a leasehold interest, or other form of operating rights, or working interest.

(d) Intangibles may be incurred prior or subsequent to the formal grant or assignment of operating rights.

(e) If a drilling or development project is undertaken for the grant or assignment of a fraction of the operating rights only that part of the intangibles which is attributable to such fractional interest may be expensed.

(f) Intangibles (as well as tangible costs) to the extent allocable to operating rights held by others must be capitalized as the depletable capital cost of the fractional interest thus acquired. 
In the simplest of farmout agreements, the farmee agrees to drill and equip a well free of cost to the farmor in return for the assignment of a $1 / 2$ interest in a lease. Under the rules in Regulation 1.612-4 (a) the farmee-operator may expense only $1 / 2$ of the free well intangibles and he must capitalize $1 / 2$ in leasehold costs. This is because the share of intangibles which may be expensed can be no greater than the operator's share of the operating interest. Farmor cannot expense any intangibles because he did not incur them. Thus the operator loses legitimate income tax deductions under this arrangement.

To avoid the loss the draftsman must arrange for the farmee to acquire all of the operating rights so that he can claim all of the free well intangible deductions. The Canadian draftsman who is relatively unfamiliar with United States income tax law will find little guidance in Regulation 1.612-4 (a) as to what contractual arrangements should be made between farmor and farmee. Some of the questions raised by that Regulation are:

(a) Must there be a formal grant or assignment in the farmout agreement of the operating rights or may the farmee be "deemed" to have them?

(b) What is the areal and vertical extent of the operating rights? Has farmee qualified under Regulation 1.612-4 (a) if it owns all of the operating rights from surface to total well depth within a drilling spacing unit? Must farmee own all of the vertical rights or may certain producing zones be owned in part by farmor?

(c) Must farmee have at least the right to acquire the operating rights during the time he incurs the intangible costs or may the right thereto be postponed until he has met his commitments in respect of the free well?

(d) What interest may the non-operating party retain in the property held by operator? After the intangible costs are recovered from production may it re-acquire a part of the operating interest given to farmee and may the re-acquisition be automatic upon recovery of the intangibles or only at the option of the nonoperating party?

(e) For what period must farmee hold, or have the right to hold, all of the operating right?

In Canada experience indicates that there is not complete agreement in the petroleum industry about how arrangements under section 263 (c) should be handled. A common, and it is thought the best, arrangement to ensure that operator is able to expense all of the free well intangibles is for the farmee to obtain from the farmor, prior to the free well being spudded, an assignment or the right to an assignment of all of the operating rights relating to the drilling spacing unit on which the free well is to be drilled, and for farmor to retain a nonoperating interest (usually a net profits interest which permits it to participate in the income from the well) until payout,"s" at which time the farmor may convert its interest to a fraction of the operating interest.

31 "Payout" is the period ending when the gross income attributable to all of the operating interests in a well equals the cost of drilling and equipping (both tangible and intangible) the well plus the cost of operating the well to produce the gross income. 
Under this arrangement the farmor is in no less favourable an income tax position either under the Code or the Income Tax Act. Under the Code, farmor would not qualify as an operator nor could it deduct any intangible costs which it did not incur. Under the Income Tax Act, the farmor can claim no deduction for the intangibles, even if the well is drilled on its lands. In Canada the income tax principle applied is "no risk, no write-off." 3 i

In making the arrangements required by the farmee, the farmor is concerned primarily with three matters:

(a) that its retained non-operating interest is the economic equivalent of the operating interest held by farmee,

(b) that no adverse income tax consequences will result upon conversion of its non-operating interest to a fractional operating interest, and

(c) that the right to convert its non-operating interest will not be adversely affected by the rule against perpetuities.

Retention by the farmor of a $1 / 2$ net profits interest for the payout of the well should ensure it of economic equivalency. ${ }^{3 \times}$ Alternatively, the farmor may retain an overriding royalty or production payment for the payout of the well. However the alternative has a disadvantage. The amount of production to be paid to maintain economic equality may be difficult if not impossible to ascertain.

The draftsman must be mindful of the United States income tax consequences attending a conversion of the farmor's retained nonoperating interest into a fractional operating interest, presumably of greater value. In order that there be a tax free exchange, the interest given up and the interest acquired must be of "like kind". ${ }^{39}$ It is unsettled whether or not a non-operating interest is of "like kind" to an operating interest. It is believed that an unlimited overriding royalty or an unlimited net profits interest, both arising out of the working interest, would be treated as like kind to the unlimited working interest for which it was exchanged. On the other hand, if the retained nonoperating interest were subject to automatic conversion, it would prima facie be a limited interest and the Internal Revenue Service with sup-

3: Stewart, Income Tax Law and Canada's Petroleum Industry, (1962) 2 Alta. L. Rev.

3s In computing net profits under an arrangement whereby farmee drills a free well. the tangible and intangible well costs are not deducted from the gross income from the well. In the usual net profits arrangement all well operating costs, rentals and royalties are chargeable against the gross income in arriving at the well's net profits. For example. assume the gross lease income is $\$ 1,000$ and the lease expenses are $\$ 300$. The net profits from the well are $\$ 700$, which each party shares equally. Under United States percentage depletion, farmee is entitled to depletion of $27, \frac{1}{2}$ percent
of gross income, not to exceed 50 percent of net income $(271 \%$ percent of $\$ 650$ or of gross income, not to exceed 50 percent of net income (271/2 percent of $\$ 650$ or $\$ 178.50$, not to exceed 50 percent of $\$ 350$, or $\$ 175)$. Farmee may claim depletion allowance of $\$ 175$. Farmor, on the other hand, can claim percentage depletion of $271 / 2$ percent on only $\$ 350$ or $\$ 96.25$, not to exceed 50 percent of net income ( $\$ 350$
less property taxes for example of $\$ 10.00$ or $\$ 170$.) Farmor may claim depletion of $\$ 96.25$. Thus the difference in revenue after taxes, between a $1 / 2$ net profits interest and $a$ 1/2 working interest is percentage depletion on $1 / 2$ of the lease expenses. In this case, the farmor would have a smaller amount of gross income subject to depletion during payout than it would have had if it had retained an equivalent percentage working interest. Depending upon the amount of expenses charged against the gross income in computing net profits, it may be necessary, in order for the farmor to maintain economic equivalency. to take a slightly higher net profits the farmor to maintain economic equivalency, to take a slightly higher net profits interest to compensate for the loss of depletion. The diference in revenue after
taxes between a 50 percent net profits interest and a 50 percent working interest is percentage depletion on 50 percent of the expenses of operating the well. On the other hand, the loss of depletion, it may be argued, is more than offset by the possibility of production in which farmor can participate at no cost or risk. In the same case, under the Income Tax Act the farmor, if it is entitled to depletion, would be entitled to a lower rate of depletion from $331 / 3$ percent of net income to 25 percent of gross income.

3o Under the Income Tax Act this is no problem. 
port of the United States Tax Court maintains that limited and unlimited interests may not be exchanged tax free under section 1031 of the Code. ${ }^{40}$ In such a case, the tax would be measured by the difference between the tax basis of the interest retained and the fair market value of the interest for which it was exchanged.

The farmor's concern about maintaining economic equivalency extends to the time that its conversion option may be exercised. The option may not be exercised until payout of the well, which may never occur or which may occur only after a period of time in excess of the period in which interests must vest under the rule against perpetuities. The farmor's concern is that the farmee may invoke the rule. An automatic conversion within the time permitted by the rule would appear to be the answer to avoiding its application, but the Internal Revenue Service has indicated that the conversion must be optional at payout; otherwise, the automatic conversion may have the effect of reducing the amount of intangibles that the farmee may expense."1

Typical operating agreements in Canada contain a "perpetuities clause" which provides that:

The right of any party to acquire an interest from the other party [i.e., the right of the non-drilling party to acquire from the operator an operating interest in the free well] shall not extend for a longer period than the lifetime of the lawful descendants now living of Her Majesty Queen Elizabeth II and 21 years thereafter.

The effect of this clause on the conversion option is to permit exercise of it at any time within the time mentioned in the perpetuities clause but not thereafter. It cannot be said that because the option is exercisable only within the time permitted by the clause that it amounts to an automatic conversion and thus the farmee loses a portion of its deductible intangibles. This is so because the farmor may elect not to exercise the option and let it expire. If payout extends beyond the time permitted by the rule it is unlikely that the conversion rights are valuable anyway.

Armed with the foregoing, the draftsman may proceed to draft the farmout agreement with greater assurance of what are the objectives of his task. In drafting provisions to give effect to the foregoing, the following guidelines may be useful:

(a) Farmee should, prior to incurring the intangibles, obtain an assignment or the right to assignment of all the operating rights in the drilling spacing unit for the free well and retain the same for payout of the well.

(b) Farmor should retain a non-operating interest (preferably a net profits interest) in the production income from the spacing unit which interest should be convertible to a fractional working interest upon payout of the well at the option of the farmor. Automatic conversions are to be avoided.

(c) If farmor retains a net profits interest the net profits should be computed without any deduction for tangible or intangible well costs to ensure that farmor gets a free well.

40 Section 1031 (a) provides that: "No gain or loss shall be recognized if property held for productive use in trade or business or for investment . . . is exchanged solely for property of a like kind to be held either for productive use in trade or business or for investment." Section 1031 (b) and (c) deal, respectively, with gain and loss from exchanges not solely in kind.

41 This is so because it may be said that in substance the farmee had the right to acquire or was in control of acquisition of less than a full operating interest. 